\title{
Formulasi Sediaan Gel Basis HPMC Ekstrak Etanol Daun Jarak Cina (Jatropha multifida) sebagai Penyembuhan Luka Sayat pada Tikus Putih (Rattus norvegicus)
}

\author{
Nurfiddin Farid1, Ummu Kalsum² ${ }^{2}$ A. Juaella Yustisi ${ }^{3}$, Resky Wahyuli4 \\ 1234 Program Studi S1 Farmasi, Fakultas Farmasi, Universitas Megarezky, Makassar, Selawesi Selatan, Indonesia
}

DOI : https://doi.org/10.29303/sjp.v1i2.25

\section{Article Info}

Received : 2020-08-04

Revised : 2020-09-29

Accepted : 2020-09-29

\begin{abstract}
Abstrak: Currently many studies are developing plants that are efficacious for traditional treatments. Which can be used as traditional medicine is Chinese jatropha plant (Jatropha multifida L.) Based on hereditary empirical experience, it is widely used by the community especially Jeneponto, Bulusibatang Village to heal new wounds. In Bulusibatang Village better known as ampicillin plant (chinese jatrophaleaf). Utilization of medical plants still needs to be explored and developed based on in-depth research and study in line with technological advances. Therefore, researchers want to continue research by making pharmaceutical preparations to facilitate their topical use, namely the preparation of Chinese castorian ethanol extract gel (Jatropha multifida L.) to treat cuts in white rats (Rattus novergicus). This research is a laboratory experimental study, which is the Effectiveness Test of Chinese Jatropha (Jatropha multifida L.) gel extracts on wound healing in white rats (Rattus novergicus). Data from observations were analyzed using statistical analysis methods namely analysis of variance (ANOVA) to determine the average treatment group and control group. Based on the results of the study, Bioplacenton positive control is more effective than negative control. And the concentration of Chinese jatropha leaf extract (Jathropha multifida) gel at a concentration of $15 \%$ which is the most effective in healing wound cuts compared to $5 \%$ and $10 \%$ concentrations.
\end{abstract}

Keywords: Chinese Jatropha Leaves, HPMC Base Gel, Vegetable Wounds, White Rat (Rattus norvegicus)

Citation: Farid, N., Kulsum, U., Yustisi, J., Wahyuli, R. (2019). Formulasi sediaan gel basis HPMC ekstrak etanol daun jarak cina (Jatropha multifida) sebagai penyembuhan luka sayat pada tikus putih (Rattus norvegicus). Sasambo Journal of Pharmacy, 1(2), 57-62. doi: https://doi.org/10.29303/sjp.v1i2.25

\section{Pendahuluan}

Indonesia merupakan negara yang memiliki banyak keanekaragaman hayati, hal ini dapat dilihat dari banyaknya tanaman yang tumbuh di Indonesia. Saat ini banyak penelitian yang mengembangkan tanaman berkhasiat untuk pengobatan tradisional. Salah satu tanaman yang dapat digunakan sebagai obat tradisional adalah tanaman Jarak cina (Jatropha multifida L). Tanaman jarak cina diketahui memiliki bahan aktif alkaloid, saponin, flavonid dan tanin. Zat-zat tersebut berperan penting dalam proses penyembuhan luka sebagai antibakterial, antioksidan, dan anti-inflamasi (Haryati et al, 2017).

Pemanfaatan tanaman obat masih perlu terus digali dan dikembangkan berdasarkan penelitian dan pengkajian secara mendalam seiring dengan kemajuan teknologi. Dengan demikian kemajuan teknologi berperan mendukung keberadaan dan peranan 
tanaman obat dalam memenuhi kebutuhan dasar kesehatan masyarakat (Sundaryono, et al, 2016).

Jarak cina (Jatropha multifida L), Berdasarkan pengalaman empiris secara turun temurun banyak digunakan oleh masyarakat khususnya Jeneponto, Desa Bulusibatang untuk menyembuhkan luka baru, Di Desa Bulusibatang lebih dikenal dengan tanaman ampicillin (Daun Jarak cina).

Hasil uji fitokimia daun jarak cina mengandung senyawa kimia yaitu golongan senyawa flavonoid fenol dan tanin, flavonoid merupakan antimikroba yang mampu membentuk senyawa kompleks dengan protein ekstraseluler terlarut serta dinding sel mikroba. Flavonoid bersifat anti inflamasi sehingga dapat mengurangi peradangan serta membantu mengurangi rasa sakit, bila terjadi pendarahan atau pembengkakan pada luka. Selain itu flavonoid bersifat antibakteri dan antioksidan serta mampu meningkatkan kerja sistem imun, karena leukosit sebagai pemakan antigen lebih cepat menghasilkan dan sistem limfoid lebih cepat diaktifkan. Senyawa fenol memiliki kemampuan untuk membentuk senyawa kompleks dengan protein melalui ikatan hidrogen, sehingga dapat merusak membran sel bakteri (Yunita et al,2018).

Tanin berperan menghambat hipersekresi cairan mukosa dan menetralisir protein inflamasi. Senyawa tanin mengandung senyawa antibakteri dimana senyawa tersebut membantu mengkerutkan dinding sel atau membran sel sehingga menghambat permeabilitas bakteri untuk berkembang. Selain itu senyawa tanin yang juga berperan dalam proses penyembuhan luka sayat, tanin bermanfaat sebagai astrigen dimana astrigen akan menyebabkan permeabilitas mukosa akan berkurang dan ikatan antara mukosa menjadi kuat sehingga mikroorganisme dan zat kimia iritan tidak dapa masuk ke dalam luka (Yunita et al,2018).

Sebagai organ tubuh letaknya paling luar dan berfungsi sebagai barier tubuh, kulit mudah mengalami luka. Perawatan dalam penyembuhan luka secara medis bisa diolesi preparat antibiotik atau gel penutup luka. Sebelum gel penutup luka dan cairan antiseptik dengan berbagai merek dipasaran, secara tradisional sejumlah tanaman dan hewan telah digunakan untuk mencegah peradangan dan penyembuhan luka (Dewi, 2015).

Gel merupakan sediaan topikal yang memiliki kelebihan dibandingkan dengan sediaan topikal lain. Gel memiliki kemampuan penyebaran yang baik pada kulit, efek dingin, tidak ada penghambatan fungsi rambut, fungsi fisiologis, kemudahan pencuciannya dengan air, dan pelepasan obatnya baik (Voight,1995).

Penelitian Darmawi dkk (2013) memberikan hasil bahwa getah Jarak cina dapat menghambat pertumbuhan bakteri Staphylococcus aureus secara in vitro. Getah Jarak cina memiliki daya antimikroba terhadap bakteri patogen Staphylococcus aureus karena adanya kandungan zat-zat aktif antara lain flavonoid dan tanin (Muntiaha, et al, 2014).

\section{Metode}

\section{Pengambilan sampel}

Sampel penelitian yang digunakan Daun Jarak cina Dari Desa Bulusibatang, Kecamatan Bontoramba, Kabupaten Jeneponto, Provinsi Sulawesi Selatan. Daun Jarak cina di cuci dan ditiriskan, kemudian dipotongpotong atau dirajang kemudian diangin-anginkan ditempat yang tidak terkena sinar matahari langsung. Daun jarak cina yang telah kering di blender hingga halus.

\section{Pembuatan ekstrak daun jarak cina (Jatropha multifida $L$ ) dengan metode maserasi.}

Simplisia segar yang diekstraksi sebanyak 600 gram sampel daun Jarak cina yang telah dikeringkan dimasukan kedalam toples kaca, lalu ditambahkan pelarut etanol $96 \% 500 \mathrm{ml}$ sampai $1 \mathrm{~cm}$ diatas permukaan sampel dan ditutup rapat serta terhindar dari cahaya matahari langsung. Proses perendaman dilakukan selama 3 hari sambil diaduk $1 \times 24$ jam. Setelah 3 hari, campuran simplisia dan etanol disaring mengunakan kertas saring sehingga diperoleh ekstrak cair, Dipekatkan dengan mengunakan rotary evaporator pada suhu $40-45^{\circ} \mathrm{C}$ sampai diperoleh ekstrak kental.

Tabel 1. Rancangan konsentrasi (\%) formula gel ekstrak etanol daun Jarak cina (Jatropha multifida)

\begin{tabular}{|c|c|c|c|c|}
\hline Bahan & Kegunaan & FI & FII & FIII \\
\hline Ekstrak & Zat aktif & 5 & 10 & 15 \\
\hline \multicolumn{5}{|l|}{$\begin{array}{l}\text { Daun jarak } \\
\text { cina }\end{array}$} \\
\hline HPMC & Basis gel & 3 & 3 & 3 \\
\hline Natrium & Pengawet & 0,1 & 0,1 & 0,1 \\
\hline \multicolumn{5}{|l|}{ Benzoat } \\
\hline Gliserin & Humektan & 10 & 10 & 10 \\
\hline \multirow[t]{2}{*}{ Air suling } & Pelarut & $100 \mathrm{Ad}$ & 100 & 100 \\
\hline & & & $\mathrm{Ad}$ & Ad \\
\hline
\end{tabular}

\section{Pembuatan sediaan Gel}

Disiapkan semua bahan-bahan yang digunakan. Bahan ditimbang sesuai dengan formula yang ada. Gel dibuat dengan cara HPMC didespersikan kedalam air panas kemudian dihomogenkan, ditambah natrium benzoat, digerus hingga homogen pada wadah yang berbeda ekstrak daun jarak cina dilarutkan dengan gliserin kemudian campuran ekstrak daun jarak cina dicampur dengan basis HPMC yang telah 
dibuat, dihomogenkan kembali hingga berbentuk massa gel.

\section{Evaluasi sediaan formula}

Dalam penetilian ini peneliti melakukan beberapa uji untuk mengevaluasi sediaan gel ekstrak daun Jarak cina (Jatropha multifida) yang terdiri dari beberapa uji seperti :

1. Organoleptik

Uji organoleptik dilakukan secara visual dan dilihat secara lansung bentuk, warna, bau, dari gel yang di buat. Gel biasanya jernih dengan konsentrasi stengah padat (Ansel, 2014).

2. Homogenitas

Pengujian homogenitas dilakukan dengan cara sampel gel dioleskan pada keping kaca atau bahan transparan lain. Sediaan harus menunjukkan susunan yang homogen dan tidak terlihat adanya butiran kasar (Ditjen POM, 1985).

3. Uji pH

Dilakukan dengan penimbangan 10 gram sediaan dilarutkan dalam $50 \mathrm{ml}$ Aquadest dalam beaker glass, ditambahkan aquadest hingga 100 $\mathrm{ml}$ lalu aduk hingga merata. Larutan diukur $\mathrm{pH}$ nya dengan $\mathrm{pH}$ meter yang sudah dikalibrasi. Ukur $\mathrm{pH}$ meter dan catat $\mathrm{pH}$ yang ditunjukkan. Hasil pengukuran menunjukan target $\mathrm{pH}$ pada kulit, yaitu 4,5-6,5 (Naibaho, 2013). pH kulit yaitu 5-6,5 (Voigt, 1994).

4. Uji Daya sebar

Gel ditimbang sebanyak 0,50 gram kemudian diletakkan ditengah kaca bulat berskala. Di atas gel di letakkan kaca bulat lain atau bahan transparan lain dan pemberat sehingga berat kaca bulat dan pemberat 150,00 g, diamkan selama 1 menit, kemudian dicatat diameter penyebarannya. Daya sebar gel yang baik antara 5-7 cm (Robertus, et al, 2015).

\section{Perlakuan Terhadap hewan coba}

Sebelum dilakukan penyayatan, tikus terlebih dahulu dianestesi menggunakan eter. Tandai bagian punggung tikus yang akan dibuat luka. Cukur bulu tikus pada bagian yang akan disayat dan dibuat luka. Kemudian bagian yang akan dibuat luka tersebut dibersihkan dengan kapas yang mengandung alkohol $70 \%$. Buat luka dengan menyayat kulit tikus menggunakan pisau bedah yang sudah steril (bilas dengan alkohol 70\%) sampai sobek jaringan otot (Eriadi, et al, 2015).

Buat luka dengan panjang $2 \mathrm{~cm}$ dengan kedalaman $2 \mathrm{~mm}$. Luka yang dibuat sayatan, yaitu pada tikus, ditandai dengan spidol dan diukur menggunakan jangka sorong. Hewan yang digunakan adalah 15 ekor, Pada setiap kelompok terdiri dari 3 Tikus putih, diberikan perlakuaan sebagai berikut :

1. Kelompok 1: Luka sayat tidak diobati (Basis gel HPMC).

2.Kelompok 2: Luka sayat diberi gel Bioplacenton, ( $3 x$ sehari).

3.Kelompok 3 : Luka sayat diberi gel ekstrak daun jarak cina $5,10,15 \%,(3 x$ sehari).

Perlakuan dilakukan setiap hari pada jam yang sama, dioleskan gel ekstrak daun jarak cina 5, 10, 15\% dan sediaan Bioplasenton sebanyak 3\%. Pengukuran panjang luka sayat menggunakan jangka sorong dilakukan setiap hari. Parameter yang dipakai dalam penentuan kesembuhan luka adalah penurunan luas luka, panjang dan diameter luka.

\section{Hasil dan Pembahasan}

Hasil evaluasi sediaan gel dapat dilihat pada tabel 2.

Tabel 2. Hasil evaluasi sediaan gel

\begin{tabular}{cccc}
\hline Formula gel & Bau & Warna & Tekstur \\
\hline Kontrol (-) & Khas & Bening & Kental \\
& Basis & & \\
Gel 5\% & Khas & Hijau & Kental \\
& ekstrak & kehitaman & \\
Gel 10\% & Khas & Hijau & Kental \\
& ekstrak & kehitaman & \\
Gel 15\% & Khas & Hijau & Kental \\
& ekstrak & kehitaman & \\
\hline
\end{tabular}

Berdasarkan tabel diatas merupakan hasil pengujian organoleptik yaitu Bau, warna, tekstur kontrol (-) gel ekstrak etanol daun Jarak cina(Jatropha multifida).

Tabel 3. Hasil uji homogenitas sediaan gel

\begin{tabular}{cc}
\hline Konsentrasi basis HPMC gel 3\% & Homogen \\
Konsentrasi ekstrak etanol daun & Homogen \\
Jarak cina 5\% & Homogen \\
$\begin{array}{c}\text { Konsentrasi ekstrak etanol daun } \\
\text { Jarak cina 10\% }\end{array}$ & Homogen \\
$\begin{array}{c}\text { Konsentrasi ekstrak etanol daun } \\
\text { Jarak cina 15\% }\end{array}$ & \\
\hline
\end{tabular}

Tabel 4. Hasil uji pH sediaan gel

\begin{tabular}{cc}
\hline Kontrol (-) & $\mathrm{pH6,5}$ \\
\hline $\begin{array}{c}\text { Gel ekstrak etanol daun jarak cina } \\
\text { (Jatropha multifida) } 5 \%\end{array}$ & $\mathrm{pH} 6,0$ \\
$\begin{array}{c}\text { Gel ekstrak etanol daun jarak cina } \\
\text { (Jatropha multifida) } 10 \%\end{array}$ & $\mathrm{pH} 5,7$ \\
$\begin{array}{c}\text { Gel ekstrak etanol daun jarak cina } \\
\text { (Jatropha multifida)15\% }\end{array}$ & $\mathrm{pH} 5,9$ \\
\hline
\end{tabular}


Tabel 5. Hasil uji daya sebar sediaan gel

\begin{tabular}{cccc}
\hline Sediaan & $\begin{array}{c}\text { Berat } \\
\text { sampel }\end{array}$ & Waktu(menit) & Hasil \\
\hline $\begin{array}{c}\text { Kontrol } \\
(-)\end{array}$ & 0,50 gram & $01: 00.370$ & sampai \\
$5 \%$ & 0,50 gram & $01: 00.470$ & $\begin{array}{c}5 \mathrm{~cm} \\
\text { sampai } \\
6 \mathrm{~cm}\end{array}$ \\
$10 \%$ & 0,50 gram & $01: 00.190$ & $\begin{array}{c}\text { sampai } \\
7 \mathrm{~cm}\end{array}$ \\
& & & sampai \\
$15 \%$ & 0,50 gram & $01: 00.700$ & $7 \mathrm{~cm}$ \\
\hline
\end{tabular}

Berdasarkan table 1 diatas merupakan hasil pengujian daya sebar dimana kontrol (-) berat sampel 0,50 gram dengan waktu 01:00.37 menghasilkan ukuran 0 sampai $5 \mathrm{~cm}$. K onsetrasi $5 \%$ berat sampel 0,50 gram dengan waktu 01:00.47 menghasilkan ukuran 0 sampai $6 \mathrm{~cm}$. Konsetrasi $10 \%$ berat sampel 0,50 gram dengan waktu 01:00.19 menghasilkan ukuran 0 sampai 7. Dan konsetrasi $15 \%$ berat sampel 0,50 gram dengan waktu 01:00.70 menghasilkan ukuran 0 sampai $7 \mathrm{~cm}$. dimana uji daya sebar gel yang baik antara 5-7 cm (Robertus, et $a l, 2015)$.

Penelitian ini digunakan hewan uji tikus putih yang berjumlah 15ekor tikus putih yang dibagi dalam 5 kelompok perlakuan selama 14 hari. Kelompok pertama merupakan kelompok kontrol negatif yang hanya diberi basis gel HPMC, kelompok kedua kelompok positif diberi Bioplacento, kelompok ketiga diberi ekstrak etanol daun Jarak cina 5\%, kelompok keempat diberi ekstrak etanol daun Jarak cina 10\% dan kelompok kelima diberi ekstrak etanol daun Jarak cina $15 \%$. Alasan penggunaan kontrol negatif pada hewan uji karna hanya digunakan sebagai pembanding dari variabel lain yang menghasilkan efek tetapi tidak efektif dengan kontrol positif yang cenderung efektif dalam pengujian.

Alasan penggunaan kontrol positif Bioplacenton ${ }^{\circledR}$ merupakan antibiotik topikal yang di produksi oleh Kalbe Farma, berupa gel yang mengandung ekstrak plasenta ex bovine 10\% dan neomisin sulfat $0,5 \%$ ekstrak plasenta bekerja membantu proses penyembuhan luka dan memicu pembentukan jaringan baru, sedangkan neomisin sulfat berfungsi untuk mencegah atau mengatasi infeksi bakteri pada area luka.

Dari hasil penelitian yang dilakukan efek penyembuhan luka insisi/sayat ekstrak etanol daun Jarak cina (Jatropha multifida) pada punggung tikus dengan beberapa konsentrasi, dimana pengamatan dimulai setelah kulit tikus di insisi. Pengobatan pada luka insisi dengan menggunakan sediaan gel ekstrak etanol daun Jarak cina (Jatropha multifida) dilakukan secara topikal dengan frekuensi pemberian tiga kali sehari yaitu tiap delapan jam dengan waktu pengukuran satu kali sehari setiap 24 jam.

Pengukuran panjang luka untuk kelompok perlakuan pada hari ke-1 sampai hari ke- 14 mengalami perubahan panjang luka atau mengalami penyembuhan. Dimana pada hari pertama luka kelompok kontrol Negatif(-) basis HPMC 3\% masih terbuka dengan diameter $2,7 \mathrm{~cm}$, di hari ke- 6 tepi luka kelompok kontrol negatif mulai menyempit dengan diameter 1,0 cm, di hari ke-13 luka sembuh dan di hari ke-14 luka sayat sembuh total(penutupan luka).

Pengukuran panjang luka kelompok kontrol positif(+) Bioplacenton pada hari pertama masih terbuka dengan diameter $2,7 \mathrm{~cm}$, dan di hari ke-6 tepi luka kelompok kontrol positif mulai menyempit dengan diameter $0,9 \mathrm{~cm}$,dihari ke- 11 luka sembuh dan di hari 12,13,14 luka sayat sembuh total (penutupan luka). Pengukuran panjang luka kelompok gel ekstrak etanol 5\% daun Jarak cina (Jatropha multifida) pada hari pertama masih terbuka dengan diameter $2,7 \mathrm{~cm}$, di hari ke-6 tepi luka mulai menyempit dengan diameter luka $0,9 \mathrm{~cm}$, di hari ke-12 luka sembuh dan dihari 13,14 luka sayat sembuh total (penutupan luka).

Pengukuran panjang luka kelompok gel ekstrak etanol 10\% daun Jarak cina (Jatropha multifida) pada hari pertama masih terbuka dengan diameter $2,7 \mathrm{~cm}$, di hari ke-6 tepi luka mulai menyempit dengan diameter luka $0,8 \mathrm{~cm}$, di hari ke-12 luka sembuh dan di hari ke-13,14 luka sayat sembuh total (penutupan luka). Pengukuran panjang luka kelompok ekstrak etanol 15\% daun Jarak cina (Jatropha multifida) pada hari pertama masih terbuka dengan diameter $2,7 \mathrm{~cm}$, dan di hari ke-6 tepi luka mulai menyempit dengan diameter luka $0,6 \mathrm{~cm}$, di hari ke-11 luka sembuh dan di hari ke12,13,14 luka sayat sembuh total (penutupan luka).

Berdasarkan penjelasan di atas dapat disimpulkan bahwa kontrol positif Bioplacenton lebih efektif dibandingkan kontrol negatif. Dan konsentrasi sediaan gel Ekstrak daun Jarak cina (Jatropha multifida) pada konsetrasi $15 \%$ yg paling efektif dalam penyembuhan luka sayat dibandingkan dengan konsetrasi $5 \%$ dan $10 \%$. Pada pengujian dalam penelitian ini, peneliti menggunakan metode analisis data one way anovayang bertujuan untuk mengetahui perbedaan secara signifikan dari setiap perlakuan untuk setiap harinya. Hasil analisis data menggunakan one way anova dengan pengujian homogenitas dan penujian kesignifikan.

Pada Test of Homogeneity of Variances menunjukkan bahwa nilai signifikan rata-rata untuk perlakuan pada saat sebelum induksi, setelah induksi, hari pertama, hari keempat, hari kedelapan dan hari ke empatbelas adalah, 134, 323, 363, dihari ke empatbelas tabelnya kosong karnah datanya sama semua, dan ratarata perlakuan sembuh di hari ketigabelas. Dimana 
semua nilai signifikasinya lebih besar dari $(>0,05)$ yang menunjukkan bahwa data tersebut memiliki variansi yang sama atau dengan kata lain, data tersebut telah homogen, maka pengujian selanjutnya dapat di lakukan.

Tabel 6. Test of Homogeneity of Variances

\begin{tabular}{lcccc}
\hline & $\begin{array}{c}\text { Levene } \\
\text { Statistic }\end{array}$ & df1 & df2 & Sig. \\
\hline HARI KE 1 & 2,330 & 4 & 9 &, 134 \\
HARI KE 4 & 1,354 & 4 & 9 &, 323 \\
HARI KE 8 & 1,234 & 4 & 9 &, 363 \\
HARI KE 14 &. & 4 &. &. \\
\hline
\end{tabular}

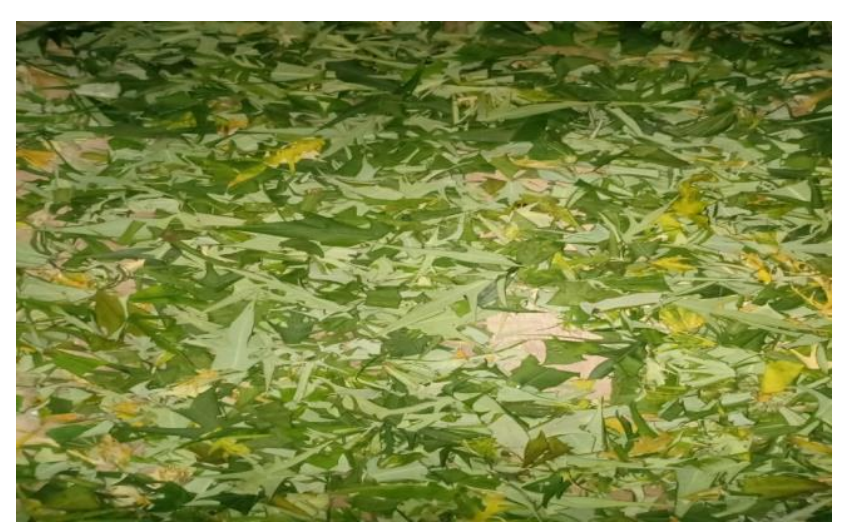

Gambar 1. Daun jarak cina (Jatropha multifida)

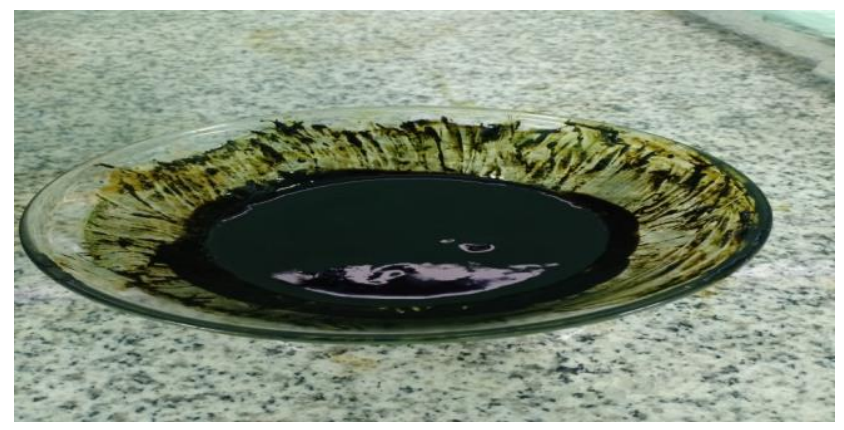

Gambar 2. Ekstrak Daun jarak cina (Jatropha multifida)

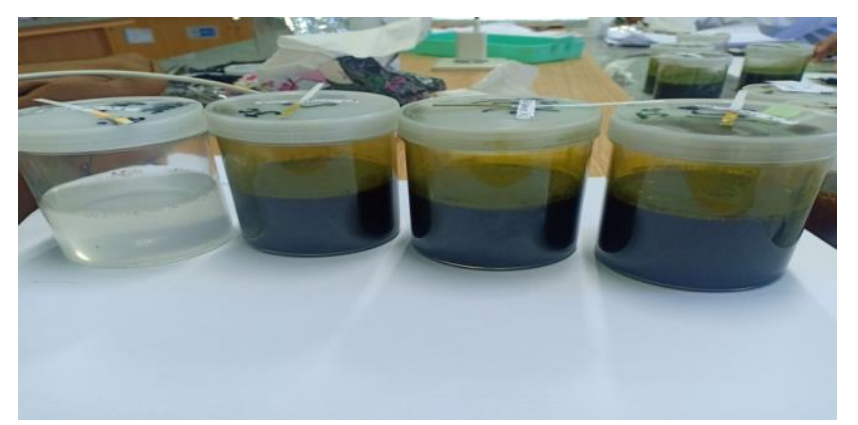

Gambar 3. Sediaan gel basis HPMC 3\% dan gel ekstrak daun jarak cina (Jatropha multifida) konsentrasi 5, 10, $15 \%$.

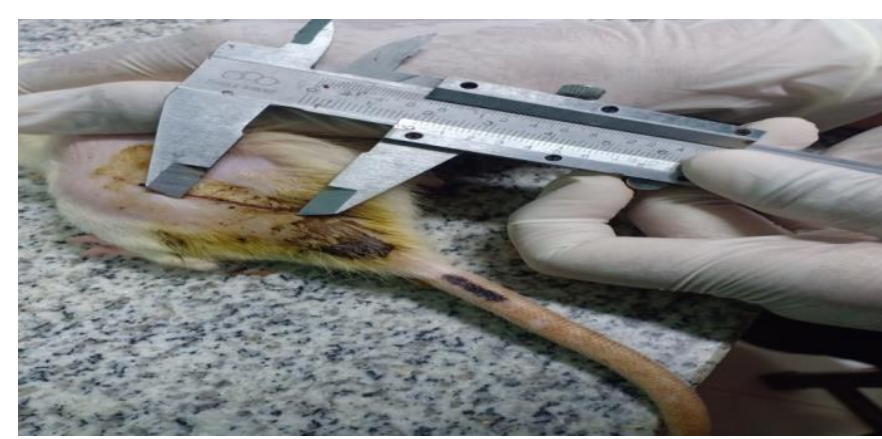

Gambar 4. Proses pengukuran hari ke- 4 tikus putih (Rattus novergicus)

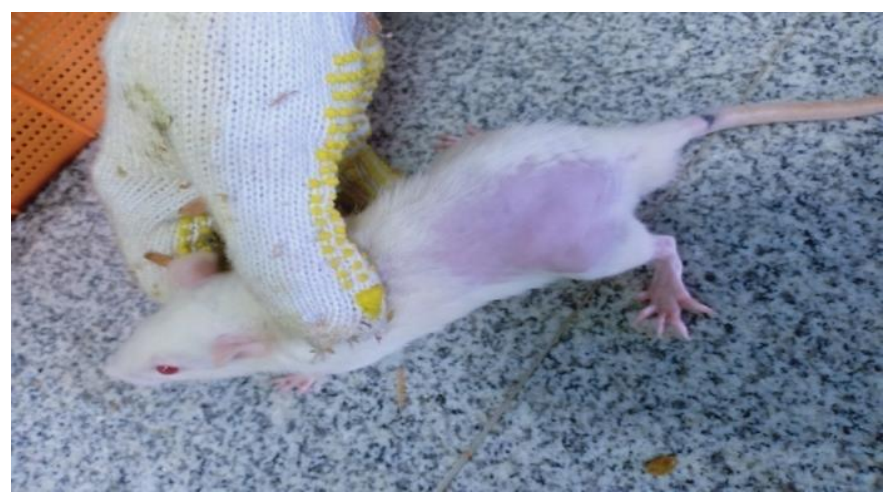

Gambar 5. Foto hari ke-14 tikus putih (Rattus novergicus). Luka sayat sembuh.

\section{Kesimpulan}

Berdasarkan hasil penelitian dapat disimpulkan bahwa kontrol positif Bioplacenton lebih efektif dibandingkan kontrol negatif. Dan konsentrasi sediaan gel Ekstrak daun Jarak cina (Jatropha multifida) pada konsetrasi $15 \%$ yg paling efektif dalam penyembuhan luka sayat dibandingkan dengan konsetrasi $5 \%$ dan $10 \%$.

\section{Daftar Pustaka}

Ansel, H. C. (2014). Pengantar Bentuk Sediaan Farmasi. Universitas indonesia Salemba, Jakarta.

Dewi, S. C. (2015). Perbedaan Efek Perawatan Luka Menggunakan Getah Pohon Yodium (Jatropha multifida L) dan Provindon Iodine 10\% Dalam Mempercepat Penyembuhan Luka Bersih Pada Marmut (Cavia porcellus). IKK. Bhakti Wiyata, Kediri.

Ditjen POM. (1985). Farmakope Indonesia. Edisi IV. Jakarta : Departemen Kesehatan Republik Indonesia.

Eriadi, et al, (2015). Pengaruh Ekstrak Etanol Daun Binahong (Andera cordifolia (Tenore) Steen) Terhadap Penyembuhan Luka Sayat Pada Tikus Putih Jantan. Fakultas Farmasi, Universitas Andalas (UNAND), Padang. 
Haryati S, et al. (2017). Perbandingan Getah Tanaman Yodium (Jatropha multifida Linn) Dengan Povidon iodin Untuk Penyembuhan Luka Bakar Pada Tikus Putih Galur (Sprague dawley). Program Studi III Farmasi Stikes Muhammadiyah Klaten.

Muntiaha, et al, (2014). Uji Efektivitas Sediaan Krim Getah Jarak Cina (Jatropha multifida L) Untuk Pengobatan Luka Sayat Yang Terinfeksi Bakteri Staphylococcus aureus Pada Kelinci (Orytolagus cuniculus). Program Studi Farmasi FMIPA UNSRAT .Manado.

Robertus, et al, (2015). Efektivitas Gel Combustio Derajat II Ekstrak Etanol Daun Senggani (Melastoma malabathricum L. Pada Tikus Jantan (Rattus novergicus). Tanjungpura Universitas, pontianak.

Sundaryono, A. Et al, (2016). Potensi Ekstrak Daun Tanaman Betadin Untuk Meningkatkan Jumlah Trombosit Penderita DBD Melalui Uji Terhadap Mus musculus, Universitas Bengkulu. Bengkulu.

Voight R, (1994). Buku Pelajaran Teknologi Farmasi. Yogyakarta : Gajah Mada Universitas Press.

Voight R, (1995). Buku Pelajaran Teknologi Farmasi. Yogyakarta : Gajah Mada Universitas Press.

Yunita. L, et al, (2018). Efektivitas Pemberian Ekstrak Daun Betadine (Jatropha multifida) Terhadap Ketebalan Jaringan Granulasi dan Jarak Tepi Luka Sayat Tikus Putih (Rattus norvegicus). Sekolah Tinggi Ilmu Kesehatan. Bina Husada, Palembang. 